\title{
Medievalista
}

Online

$24 \mid 2018$

Número 24

\section{Ensinar e Aprender na Évora Medieval}

To Teach and to Learn at Medieval Évora

\section{André Filipe Oliveira da Silva}

\section{OpenEdition}

\section{Journals}

Edição electrónica

URL: http://journals.openedition.org/medievalista/1701

DOI: 10.4000/medievalista.1701

ISSN: 1646-740X

\section{Editora}

Instituto de Estudos Medievais - FCSH-UNL

\section{Refêrencia eletrónica}

André Filipe Oliveira da Silva, «Ensinar e Aprender na Évora Medieval », Medievalista [Online], 24 | 2018, posto online no dia 16 março 2019, consultado no dia 19 abril 2019. URL : http:// journals.openedition.org/medievalista/1701 ; DOI : 10.4000/medievalista.1701

Este documento foi criado de forma automática no dia 19 Abril 2019

(C) IEM 


\section{Ensinar e Aprender na Évora Medieval}

To Teach and to Learn at Medieval Évora

André Filipe Oliveira da Silva

\section{NOTA DO EDITOR}

Data recepção do artigo / Received for publication: 07-05-2017

Data aceitação do artigo / Accepted in revised form: 12-04-2018

\section{Introdução}

1 A renovação cultural dos séculos XII e XIII, alimentada pela divulgação de inúmeros autores arabófonos, como Avicena, Averróis ou Maimónides, e pela redescoberta de outras tantas autoridades da Antiguidade no Ocidente latino - com destaque para uma parte muito relevante das obras sobre Lógica de Aristóteles e dos grandes médicosautores, como Hipócrates e Galeno -, aliada à importância crescente que o Direito escrito recuperava ao sabor da evolução das 'administrações públicas', potenciou ainda mais o desenvolvimento do ensino organizado, culminando no aparecimento e consolidação das universidades ${ }^{1}$. De facto, a oferta ia muito além dos níveis superiores, completando-se com outras escolas, elementares ou providas de uma maior especialização vocacionada para fins bem definidos.

2 Vários são os agentes desta renovação. A Igreja, que procurava centralizar cada vez mais a sua hierarquia através de uma poderosa e vasta máquina burocrática com sede na Cúria Pontifícia, demonstrava uma preocupação crescente com a formação dos ministros do culto, depositando no domínio das elites intelectuais a chave do sucesso na condução das vastas massas iletradas, na administração de uma instituição 'universal', na capacidade de produzir e arquivar vastíssimos acervos documentais, na defesa legal dos seus direitos ou no exercício de arbitragem judicial e no combate às heterodoxias². Também a burocracia 
régia e municipal começou a absorver indivíduos cujas competências haviam sido adquiridas nestes estabelecimentos. A instituição do tabelionado, a profusão de escrivães nos mais diversos órgãos e instituições, e o exercício da justiça com recurso a diversas instâncias é disso representativo. Nas margens, as minorias - com destaque para a judaica, como adiante ser verá - buscam a sobrevivência cultural e religiosa.

Évora, integrada no reino português em 1165, foi tratada desde cedo como ponto estratégico da expansão cristã a sul do Tejo. D. Afonso Henriques estabeleceu o poder municipal e episcopal em 1166, tentando consolidar um posto avançado no território. Os últimos séculos da Idade Média fazem da cidade um palco privilegiado do difícil equilíbrio entre os grandes poderes na região, disputando "o controlo de um espaço retalhado" 3 . Neste contexto, foram vários os fatores que favoreceram o desenvolvimento de diversas escolas em Évora, dirigidas por e para diferentes grupos, com as suas próprias aspirações e objetivos, cujas diversas tipologias e intenções constituem a peça central deste artigo; assim, procurou-se analisar criticamente os trabalhos sobre Évora que referem alguns dos tipos de ensino estudados, para obter uma visão integrada e transversal do ensino na realidade urbana eborense tardo-medieval, acrescentando-se novos dados documentais alguns já conhecidos, outros inéditos, mas todos eles dispersos até agora -, obtidos sobretudo através de fontes indiretas, como a documentação patrimonial das diversas instituições eborenses e da Coroa. Assim, mais do que encerrar o tema, este trabalho pretende reabri-lo e atualizá-lo.

\section{As escolas eclesiásticas}

\subsection{A escola catedralícia de Évora}

4 Tal como em muitas outras cidades episcopais, a catedral terá acolhido as primeiras manifestações de ensino organizado em Évora ${ }^{4}$. Os III e IV Concílios de Latrão, de 1179 e 1215 , respetivamente, obrigavam todas as catedrais a possuir um mestre que ensinasse futuros clérigos e meninos pobres ${ }^{5}$. Nas restantes dioceses portuguesas, as mais importantes terão contado com escolas logo a partir das respetivas restaurações: Braga em 1070-1071, Coimbra antes de 1088 e Lisboa não muito depois de $1147^{6}$. Não seria surpreendente deparar com uma realidade similar em Évora - até pelas ligações do primeiro clero eborense aos monges crúzios ${ }^{7}$. Mas, sendo possível encontrar membros do cabido eborense com um ambíguo título magistral desde $1200^{8}$, a dignidade capitular associada ao ensino, o mestre-escola, surge mais tarde e levanta uma série de problemas ${ }^{9}$. O mestre-escolado eborense integra a Lista das Igrejas de 1320-1321, conhecendo-se várias provas da sua continuidade até lhe ser anexada uma prebenda pelo bispo D. Martinho (1368-1382). Parece, contudo, constituir-se como uma figura menor, mesmo após a sua instituição como dignidade, já que continuaria subordinado ao chantre até bem depois do ocaso da Idade Média ${ }^{10}$. Sendo imprudente assumir que os sucessivos mestres documentados no século XIII fossem 'professores' na escola capitular, a existência do mestre-escola na centúria de Trezentos - não constituindo o mestre-escolado uma dignidade antes de 1370, nem sendo os seus titulares cónegos -, dá força à ideia de que seria efetivamente um lente que ensinaria na catedral ${ }^{11}$.

5 Uma das mais notáveis peculiaridades do clero catedralício eborense é o grupo dos Bacharéis da Sé, um verdadeiro 'subcabido' que garantia as exigências do culto na catedral, mesmo com o crescente absentismo dos cónegos $^{12}$. Apesar de serem apenas um 
exemplo precoce de porcionários, surgindo algures na segunda metade do século XIII ${ }^{13}$, a sua designação é problemática. Não sendo possível provar se a intitulação estava ligada a uma eventual frequência universitária, parece haver alguns indícios do envolvimento dos bacharéis nas atividades de ensino na catedral. Um alvará do Estudo Geral de Lisboa, datado de 1472, informa o cabido da matrícula do escolar Diogo de Sousa - talvez o futuro bispo do Porto e arcebispo de Braga, então com 12 ou 13 anos ${ }^{14}$ - como escolar de Gramática, provavelmente após uma introdução ao latim na escola da catedral ${ }^{15}$. Este alvará foi apresentado pelo bacharel Álvaro Gonçalves, cuja relação com o jovem escolar não é esclarecida. Seria uma espécie de tutor? Estariam os bacharéis envolvidos no ensino elementar de leitura e escrita, acompanhando os discentes que prosseguiriam estudos no momento da sua inscrição? Será apenas um caso excecional? Os sucessivos estatutos preveem, desde cedo, a possibilidade da ausência dos clérigos que se encontrem em estudos gerais, sem prejuízo dos seus benefícios, durante cinco anos; de resto, esta era uma prática corrente noutros cabidos catedralícios e corporações religiosas ${ }^{16}$. Apesar da crescente formação superior, o número de cónegos com pouca ou nenhuma literacia manteve-se alto, contrastando com os seus pares que ostentavam graus académicos. Prova disso são as disposições estatutárias do bispo D. Garcia de Meneses (1472-1484) que, em 1478, procurando combater o desconhecimento da língua latina - e até mesmo o analfabetismo - de muitos dos cónegos que iam sendo nomeados por favor pontifical ou influência régia, impede os beneficiados de tomarem parte das distribuições do Cabido caso não fossem capazes de ler o Livro dos Estatutos em cabido, mantendo-se a interdição até que o demonstrassem saber fazer ${ }^{17}$.

6 Por outro lado, a biblioteca da Sé, enriquecida por algumas doações, legados, mas também compras, possuía um interessante acervo de obras dos dois direitos e de matéria teológica 18. Refira-se, a título de exemplo, o empréstimo de vários livros a D. Duarte, então infante, registado em 1427 no Livro I de Aniversários do arquivo capitular, os quais haviam sido adquiridos pelo cabido por escambo de um curral deixado por D. Martinho Gil, bispo de Évora, para celebração de aniversários ${ }^{19}$. Verifica-se, portanto, uma política ativa de aquisição de obras potencialmente úteis na gestão e defesa dos interesses da instituição capitular, formando-se um acervo que despertaria a atenção até de um futuro rei.

7 É possível que a escola catedralícia de Évora tenha tido uma existência constante, ainda que discreta, ao longo dos últimos séculos da Idade Média. Será necessário esperar pelo episcopado dos infantes-cardeais D. Afonso (1523-1540) e D. Henrique (1540-1564 e de novo 1574-1578) para assistir à consolidação institucional e à multiplicação de escolas complementares, culminando na fundação da Universidade de Évora em 1559, e do herdeiro da escola catedralícia, o Seminário Maior de Évora - então Colégio da Purificação - que entrou em funcionamento em 1593, já após a morte do Cardeal-Rei ${ }^{20}$.

\subsection{As escolas dos conventos mendicantes}

8 Os mendicantes foram a face mais expressiva de um clero regular com fraca implantação no Alentejo medieval ${ }^{21}$. O convento franciscano de Évora foi fundado por volta de 1250 , seguido pelo dominicano, em $1286^{22}$. É sabido que a criação da Ordem dos Pregadores se encontra intimamente ligada ao combate à heresia albigense - tal como a da Universidade de Toulouse, que foi uma das várias frentes de combate a essa heterodoxia. 0 estudo representava uma parte indispensável da vida dominicana e as constituições de 1236 são explícitas na proibição da fundação de conventos onde não houvesse um prior nem 
doutor ou teólogo ${ }^{23}$. Por outro lado, ainda que os Frades Menores não tivessem, originalmente, a mesma vocação, cedo se associaram às grandes universidades e às suas elites. De facto, os mendicantes possuíram um verdadeiro monopólio no ensino de Teologia até meados do século XIV, pois apenas as Universidades de Paris, de Oxford e de Cambridge possuíam faculdades de Teologia - onde os dominicanos e franciscanos abundavam -, sendo os conventos mendicantes, por vezes equiparados a Estudos Gerais ${ }^{24}$, os responsáveis pelo ensino da mesma no resto da Cristandade. A primeira exceção dá-se em Praga, em 1347, e com o Grande Cisma de 1378-1417, os dois lados favoreceram a criação de faculdades teológicas nos Estudos Gerais dos reinos que os apoiavam ${ }^{25}$. Aliada à sua influência no ensino e na cultura, a nova espiritualidade mendicante, sobretudo franciscana, exerceu uma influência considerável na sociedade tardo-medieval, incluindo muitas famílias régias - a portuguesa não constituía exceção ${ }^{26}-$, onde abundavam os confessores menoritas e pregadores.

9 Foquemo-nos nas escolas dos conventos mendicantes de Évora. Ainda que a informação sobre esse ensino seja muito limitada para o século XIII - apenas resta a notícia dada pelo Capítulo Provincial de 1299, reunido em Barcelona, do ensino de gramática no Convento de São Domingos, que contava com sete alunos e tinha João de Estremoz como leitor e Pedro Pais como doutor ${ }^{27}$-, são conhecidos leitores dos conventos de São Francisco e São Domingos de Lisboa, assim como de São Francisco e São Domingos de Santarém, logo a partir de $1261^{28}$. Estando o ensino de Teologia proibido no Estudo Geral português até ao advento do século $\mathrm{XV}^{29}$, essa lacuna seria compensada pelas escolas mendicantes. Para São Francisco de Évora, é possível referir pelo menos um leitor ativo no século XIV: Frei Vicente, documentado no Capítulo Provincial de Coimbra de $1330^{30}$. A existência de um leitor no convento menorita de Évora demonstra já a solidez da instituição e acompanha a complexificação da rede de ensino da Ordem que justifica, por exemplo, a criação do Studium generale do convento franciscano de Lisboa em $1340^{31}$. Há ainda outros letrados mendicantes oriundos de Évora, ainda que não tivessem um vínculo conhecido aos conventos da cidade, ou o tenham tido numa fase precoce das suas carreiras. Eis alguns exemplos: Frei Estêvão, natural de Évora, franciscano do convento de Lisboa, bispo do Porto (1311) e de Lisboa (1313) ${ }^{32}$; Frei André do Prado, documentado no convento franciscano de Évora em 1380, leitor em Bolonha (1414-1416) e um dos fundadores dos Terceiros Franciscanos Seculares em Portugal (1422) ${ }^{33}$; dois dominicanos eborenses nomeados para o corpo docente do Convento de Lisboa no Capítulo Geral da Ordem de 1478: Frei Pedro Dias, como leitor do primeiro ano de Sentenças, e Frei Vasco Eborense, como leitor do segundo ano da mesma cadeira ${ }^{34}$; Frei Brás de Évora, doutor do Convento de São Domingos do Porto (1480) $)^{35}$.

10 A necessidade de formação para a pregação e missionação exigia-lhes conhecimento e arte: o ensino e a cultura eram-lhes, por isso, indispensáveis, sendo as escolas uma presença constante nas suas vidas ${ }^{36}$. As escolas clericais seculares não lhes eram destinadas - ainda que as pudessem ter frequentado antes do ingresso na ordem -, e as constantes demandas entre mendicantes e clero diocesano empolavam essa separação. As escolas mendicantes de Évora nunca assumiram um lugar destacado no panorama nacional. Porém, mesmo escassos, os testemunhos documentais parecem não deixar dúvidas quanto à sua existência permanente a partir do século XIV. 


\section{Entre os leigos}

\subsection{As escolas do Concelho}

11 A expansão do notariado, da escrita pública e do direito resultaram igualmente numa progressiva laicização do ensino, um pouco por toda a Europa. E, se a existência de escolas do município eborense é incerta para o período anterior a 1400, o século XV revela-as como um dos casos mais bem documentados para o Portugal do seu tempo. Desde logo pela necessidade: Armindo de Sousa sublinha o facto de a obrigatoriedade de ter oficiais de justiça que soubessem ler estivesse restrita aos núcleos urbanos onde o acesso a esses cargos não estaria maioritariamente reservado a uma maioria de lavradores, ou seja, onde o principal fornecedor das elites governativas locais era a burguesia urbana: Lisboa, Évora, Coimbra, Porto e Santarém ${ }^{37}$. Se os fidalgos deveriam educar os seus filhos nas próprias casas, incluindo a aprendizagem da leitura e escrita, como frisam os representantes concelhios nas Cortes de $1498^{38}$, ao povo não era possível contratar mestres privados. A existência de uma escola municipal tornava-se fundamental para a elite da cidade poder garantir um ensino regular aos seus filhos, ainda que estendendo essa possibilidade aos filhos de mesteirais, por exemplo. Garantir-se-ia assim o preenchimento de um importante requisito de acesso aos cargos públicos que favoreceriam ou consolidariam uma ascensão social que, no geral, levaria gerações a concretizar. Provável reflexo dessa realidade, a literacia na Évora quatrocentista atingiria já setores de atividade que seriam, no mínimo, inesperados. Sobrevivem vários contratos de prestação de serviços e reparações entre o Cabido da Sé e artesãos, onde o contratado colocou a sua assinatura autógrafa ${ }^{39}$. Estando longe de provar uma capacidade fluente de leitura e escrita, revela já um primeiro contacto com o ato de escrever - e com a sua utilização no quotidiano - que não pode ser desprezado.

12 Outros testemunhos parecem confirmar este acesso alargado a níveis básicos de aprendizagem formal. Em 1466, os representantes eborenses às Cortes informam o rei da existência de um bacharel, pago pelo Concelho, que ensinava "gramática e a escrever aos filhos dos bons e a quaisquer outros que querem aprender", queixando-se que o corregedor da Corte havia reduzido a tença anual do bacharel de 3500 para 2000 reais, levando este a querer abandonar o cargo. 0 rei decide em favor do Concelho, limitando a tença, contudo, a um máximo de 3000 reais $^{40}$. Este testemunho confirma o estatuto de escola pública e teoricamente acessível a todos. Não sendo claro que a realidade fosse tão linear, parece haver, pelo menos, uma postura 'oficial' da oferta deste ensino como uma responsabilidade do poder local.

13 Alguns anos mais tarde, em agosto de 1481, o Concelho solicita ao príncipe D. João, futuro D. João II, a validação da substituição do bacharel Linhares, que até então ensinara em Évora e de alguma forma desagradara o Concelho, por Estêvão Cavaleiro. O futuro rei ordenou que fosse examinado e, confirmando-se que estava preparado e era idóneo, fosse conduzido nas funções e lhe fossem concedidas a tença e as liberdades do cargo ${ }^{41}$, o que revela a constância do serviço prestado pelo Concelho no final do século XV. $\mathrm{O}$ amadurecimento do poder concelhio tardo-medieval trouxe um conjunto de novas preocupações aos municípios, que chamavam a si, cada vez mais, a responsabilidade da gestão e garantia do bem comum. A instrução e a higiene pública estão entre as mais expressivas. 


\subsection{Uma escola privada de gramática de um leigo, ou a rua de um lente eclesiástico?}

14 Vários documentos do início do século XV referem um enigmático Estêvão Eanes, identificado como "aquele que ensina os moços a ler", e do qual temos notícias por ter dado o seu nome a uma rua enquanto nela esteve instalado. Esta "rua de Estêvão Eanes, que ensina os moços a ler" estaria próxima de São Domingos, e dela temos notícia em 1401, 1405 e $1435^{42}$, sendo referida como a "rua onde morou Estêvão Eanes que ensinava os moços a ler" em $1435^{43}$ e $1445^{44}$. Mesmo não se sabendo ao certo quem terá sido, parece verosímil que tenha deixado de ensinar em 1435, ou até antes: um documento de abril desse ano refere-o no passado, enquanto um de novembro o refere no presente - sinal, talvez, de uma morte recente. Apesar do intervalo entre os anos referenciados, é possível que a atividade deste mestre tenha durado várias décadas, cobrindo o primeiro terço do século XV. Estaríamos perante uma pequena escola privada de gramática? É possível. Não há qualquer título académico ou magistral associado a Estêvão Eanes. Se assim fosse, não seria estranho que fosse pago, na totalidade ou em parte, pelo Concelho da cidade, mas não existe qualquer prova dessa ligação. Seria um bacharel que fez carreira como professor? A informação toponímica não o esclarece. Há menção a um Estêvão Eanes que terá sido estudante de Direito Civil durante cinco anos e para quem, após esse período, é reservado um benefício no Cabido da Sé de Évora, por bula do papa Bonifácio IX, após súplica do rei D. João I, em $1389^{45}$. Não há provas de que tenha alcançado o canonicato ${ }^{46}$, ainda que pudesse ter sido provido noutro benefício, como o de ter sido feito bacharel da Sé, o que nos transportaria para uma outra dimensão de ensino e enquadramento institucional. A coincidência das duas figuras é, por ora, uma possibilidade em aberto, tal como todas as restantes hipóteses levantadas em torno de Estêvão Eanes. Porém, resta a certeza de se tratar de uma figura conhecida na cidade onde vivia pela atividade de ensino que exercia.

\subsection{Transmissão de conhecimentos e legitimação pública de ofício}

15 A cidade medieval reunia um conjunto de profissionais cuja preparação especializada, tanto prática como teórica, ia além da mera aprendizagem da leitura e escrita. Alguns destes ofícios estão associados ao mundo universitário. Contudo, esta não parece ter sido uma opção comum na Évora medieval, a menos que coincidisse com o desejo de prosseguir uma carreira eclesiástica. Como seriam obtidos o conhecimento e a prática necessária? Focar-me-ei num conjunto paradigmático de ofícios: os da cura e os da escrita. Porei de lado boticários e barbeiros, pela sua natureza mercantil e empírica, respetivamente, concentrando-me nos físicos e cirurgiões. No que à escrita concerne, focar-me-ei no caso particular dos tabeliães. Estas opções são questionáveis: considerar a transmissão de conhecimentos entre ofícios poderia incluir 'todos' os ofícios. Porém, aqueles que aqui são analisados integram um grupo especial cujo exercício implicava o reconhecimento de competências por parte de autoridades públicas, exigindo uma preparação considerável e o domínio de um conjunto alargado e padronizado de conhecimentos teóricos e práticos.

16 Ângela Beirante identificou mais de seis dezenas de físicos e cirurgiões atuantes em Évora durante a Idade Média ${ }^{47}$. Destes, dois terços eram judeus. Uma parte destes indivíduos é 
conhecida através das suas cartas de ofício, isto é, pelo registo da sua examinação e consequente licenciamento de atividade por parte do físico-mor. Iria Gonçalves estudou as cartas de ofício de físico e cirurgião preservadas nas chancelarias régias quatrocentistas, reunindo dados muito relevantes para desvendar o tipo de formação destes homens ${ }^{48}$. Nenhum indivíduo das centenas de candidatos examinados e aprovados refere uma frequência universitária. De resto, tal seria quase impossível para um judeu, por exemplo. O exame seria prático e teórico, e o candidato deveria revelar um conhecimento suficiente das autoridades greco-arábicas. Além da possibilidade da obtenção do conhecimento especializado num Estudo Geral - impossível de apurar na maioria dos casos e talvez inexistente em boa parte - resta aos físicos e cirurgiões da Évora medieval - à semelhança do que acontecia no resto do território português -, uma formação não-universitária ${ }^{49}$. Esta aprendizagem teria como base a instrução junto de um mestre, prolongada por vários anos, até aquele considerar o discípulo apto a apresentarse a exame junto do físico-mor. Este tipo de ligação pode ser detetado nos registos de exame: em 1444, Mestre Abraão, criado de Mestre Moisés, físico, recebe carta de cirurgião 50; em 1464, Mestre Abraão Abeacar, criado de Mestre Eleazar, recebe carta de cirurgião ${ }^{51}$ - é ainda possível que seja filho ou irmão de Mestre José Abeacar, outro físico eborense examinado em $1453^{52}$. Em 1473, é a vez de outro criado de Mestre Eleazar, Leão Abeacar provavelmente aparentado com os anteriores -, ser examinado na arte da cirurgia ${ }^{53}$. Termino com uma referência ao filho do próprio Mestre Eleazar, José Dono, a quem D. Afonso V, em 1473, concede carta de privilégio para andar em besta muar de selo e freio, designando-o como "discípulo de cirurgia", numa rara referência a um indivíduo em plena formação ${ }^{54}$. Os físicos e cirurgiões de Évora, sobretudo o contingente judeu, constituiriam uma comunidade de conhecimento relativamente endogâmica, garantindo simultaneamente uma aprendizagem sólida, a passagem de testemunho e a manutenção do status dessas profissões, que D. Duarte, no Leal Conselheiro, coloca no terceiro e mais alto estrato do povo, entre "os que usam de algumas artes aprovadas e mesteres" 55 . Estariam, por certo, recetivos a novos conhecimentos e em contacto com outras comunidades de físicos judeus. Dominariam as obras das autoridades e, mesmo após a expulsão ou conversão forçada, D. Manuel I abriu exceções para que cristãos-novos possuíssem livros de medicina em hebraico, como é o caso de Mestre Luís, físico cristãonovo e morador em Évora, a quem é concedida essa licença em $1499^{56}$.

Outro exemplo deste tipo de comunidades é a dos tabeliães ${ }^{57}$. Não se conhece qualquer tabelião em Évora antes de $1251^{58}$. De resto, esta ausência verifica-se em todo o Alentejo. Após essa data, o tabelionado desenvolve-se rapidamente, havendo várias dezenas de tabeliães documentados até 1500. Contudo, estes ainda não mereceram a atenção particular que outras cidades já receberam ${ }^{59}$. Não sendo o meu objetivo historiar o tabelionado medieval eborense, resta-me tecer algumas observações sobre este ofício e o seu licenciamento de atividade. Em primeiro lugar, a sua condição social: não são aristocratas nem são, segundo a normativa do ofício, eclesiásticos ${ }^{60}$. Falamos de um grupo de indivíduos com um cargo de importância pública, letrado e aparentemente alheio ao clero. A origem do tabelionado está intimamente ligada ao ressurgimento do Direito Romano, tendo-se desenvolvido uma vasta produção bibliográfica e normativa ao longo do século XII e XIII, quer no Sacro Império, quer na Cúria Pontifícia ${ }^{61}$. Os manuais e formulários difundiam-se rapidamente e Portugal não ficou fora desta esta expansão $0^{62}$.

18 Não temos dados concretos sobre a aprendizagem dos tabeliães portugueses e não se conhece nenhuma escola especializada. Contudo, e como Maria Helena da Cruz Coelho 
resume "os primeiros teriam aprendido a ler e a escrever em qualquer escola catedralícia ou monacal (...) e, uns quantos, na chancelaria régia. E depois o saber profissional aprendia-se com a prática, nas oficinas tabeliónicas" ${ }^{63}$. Estabelecido o ofício, o tabelionado tornou-se capaz de formar as gerações sucessivas de profissionais da escritura pública. Já no reinado de D. Dinis teriam de se fazer examinar pelo chanceler-mor para que pudessem exercer ${ }^{64}$, revelando um controlo de competências e reconhecimento público em tudo semelhante ao dos físicos e cirurgiões, examinados pelo físico-mor. Não é certo que essa formação tivesse lugar em Évora. Apenas o estudo da afinidade entre sinais tabeliónicos preservados na documentação, entre outros elementos, poderia estabelecer relações de aprendizagem e identificar possíveis discípulos. Até lá, mantém-se como uma possibilidade a considerar.

Não constituindo escolas, estes pequenos grupos socioprofissionais reuniam algumas características afins: a existência de uma pequena e coerente comunidade de conhecimento, com uma transmissão de saber regular, dividindo-se entre uma aprendizagem prática e teórica, onde o discípulo ora assistia, ora era assistido pelo mestre e, por fim, avaliado pelo representante oficial da Coroa para esse efeito, legitimando essa relação de ensino e o saber adquirido, assumindo legal e publicamente a profissão de físico, cirurgião ou tabelião. Estes ofícios não estarão, porém, sozinhos neste rol. A título de exemplo, refira-se um capítulo especial de Santarém, nas Cortes de 1436, solicitando a submissão dos alveitares - ou seja, veterinários - a um processo de exame semelhante ao dos físicos e cirurgiões ${ }^{65}$, o que demonstra que não só a examinação era valorizada pelas populações, mas também revelava eficácia no controlo de qualidade e legitimação de atividade. Estas "artes aprovadas e mesteres" não deixariam de formar núcleos cultos, repositórios de um saber perpetuado na relação mestre-discípulo e ampliado ao longo de gerações, colocando-se num patamar intermédio entre os mesteirais mais comuns e as elites letradas.

\section{As minorias}

Ainda que Évora não tenha ocupado um lugar de destaque no al-Andalus, figuras como a de Abd al-Majid ibn Abdun, poeta e oficial régio nascido na cidade por volta de 1050 onde voltaria inúmeras vezes ao longo da vida e onde faleceria, provavelmente já depois de 1135 -, permitem atestar o ambiente propício ao desenvolvimento da cultura erudita antes da conquista cristã ${ }^{66}$. Está documentalmente provada a ligação de mais de vinte letrados andaluzes - os ulemás - a Évora, por naturalidade, residência ou origem familiar ${ }^{67}$. Entre os letrados cuja cronologia é conhecida, são vários os que morrem bem depois da conquista cristã de Évora, o que demonstra a perenidade da memória da raiz eborense entre várias famílias ilustres.

21 O primeiro século da comuna muçulmana de Évora após o foral concedido por D. Afonso III aos mouros forros da cidade, em 1270, levanta problemas complexos: onde seria a primeira mouraria eborense? De onde viriam os mouros forros e onde habitavam? Estas e outras questões permanecem em aberto. A comuna moura de Évora, uma das mais importantes do reino, não estaria alheada da realidade portuguesa, onde continuavam a existir letrados ${ }^{68}$, sendo admissível a existência de uma escola onde o ensino do árabe com fins religiosos e jurídicos se faria, tal como está documentado na comuna de Lisboa ${ }^{69}$. De resto, em dezembro de 1362, e a pedido da própria comuna de Évora, D. Pedro I determina os moldes em que o alcaide da comuna eborense seria eleito, tendo como requisitos o 
domínio da leitura e da escrita, assim como do direito islâmico - algo que não se verificava com $o$ alcaide então em funções ${ }^{70}$.

Para a comuna dos judeus de Évora, bastante maior do que a comuna dos mouros da mesma cidade e, à semelhança desta, uma das mais importantes do reino, sobrevivem vários testemunhos de exercício formal do ensino. Lisboa e Évora são as únicas cidades do reino onde estão documentadas escolas hebraicas ${ }^{71}$, ainda que a importância fundamental que o ensino ocupa na vida das comunidades judaicas ${ }^{72}$ torne altamente improvável a inexistência de escolas nas dezenas de outras comunas judaicas existentes no Portugal medieval ${ }^{73}$. No período tardo-medieval, os níveis de alfabetização seriam elevados entre os judeus, e para muitos o estudo prolongar-se-ia por vários anos, podendo culminar numa especialização como a prática médica ou um ofício financeiro ${ }^{74}$. Esta alfabetização generalizada relacionava-se intimamente com a evolução religiosa e cultural de vários séculos, através da qual os judeus, espalhados por todo o Médio Oriente e Mediterrâneo, deixaram de ser um povo de agricultores e criadores de gado, maioritariamente analfabetos, para se tornarem um grupo de mercadores, letrados e altos funcionários, onde a educação era entendida como um investimento e como uma garantia de perenidade identitária ${ }^{75}$. Assim, não só os judeus exerciam ofícios e oficialatos prestigiantes, na Cristandade como no Islão, como se tornaram maioritários e até preferidos em vários deles.

A localização da Bet-hamidrash, Midrash ou Midras, em galego-português, é-nos dada pela toponímia medieval de Évora: a Rua do Midras e a Rua do Midras de Baixo informam-nos da presença de uma escola instalada nos edifícios confinados por esses arruamentos, onde teria lugar o ensino da exegese bíblica e do direito hebraico, onde o Midrash, típico da diáspora hebraica desde a Antiguidade, conferia identidade, memória e doutrina à comunidade. É possível que tenha havido mais do que uma escola: Maria José Pimenta Ferro assim o entende, não havendo, contudo, dados sobre o chamado Midras pequeno: é possível que se encontrasse anexo ao Midras maior e, provavelmente, mais recente. Os edifícios do Midrash seriam da comuna, tendo-os doado D. Manuel I a D. Carlos, fidalgo da sua casa, após o decreto de conversão forçada ou expulsão dos judeus e mouros portugueses ${ }^{76}$. Ainda por alguns anos se manteve a referência ao Midras Velho ${ }^{77}$, acabando por cair em desuso. Correspondendo a Rua do Midras e a Rua do Midras de Baixo às atuais travessas da Parreira e do Pocinho ${ }^{78}$, respetivamente, seria interessante perceber quanto desses edifícios poderá ter sobrevivido à passagem do tempo. Contudo, as dificuldades levantadas pelas intervenções arqueológicas na antiga Judiaria de Évora são numerosas e refletiram-se, por exemplo, na escavação levada a cabo por Carmen Ballesteros na antiga sinagoga de Évora ${ }^{79}$. Resta-nos, por ora, a memória documental dessa materialidade.

Além do Midrash propriamente dito, conhece-se um mestre judeu atuante em Évora, através de uma referência quase acidental: no livro de acórdãos quatrocentista do cabido eborense, foi anotado o aforamento de uma casa a Mestre José, para o seu primo Juda Rabi, que ensina os moços ${ }^{80}$. Este mestre poderá ter ensinado no Midrash, na Sinagoga ou ainda noutro espaço. Mesmo não existindo essa referência para Évora, conhece-se a existência de uma escola judaica para crianças em Lisboa, independente do Midrash dessa cidade $^{81}$. Outro elemento de interesse, ainda que fonte de muitas dúvidas, é o genesim. Simultaneamente tributo e oficialato, é definido por Viterbo como imposto pago para que possa haver ensino rabínico na respetiva comuna judaica ${ }^{82}$. Não sendo possível conhecer a sua fonte, fica a hipótese, conhecendo-se alguns oficiais responsáveis por este tributo em várias judiarias, incluindo a de Évora ${ }^{83}$. 
Por fim, um olhar sobre os rabis. Como chefes políticos, judiciais e religiosos de cada comunidade, era comum acumularem funções: conhecemos físicos ${ }^{84}$, doutores da lei ${ }^{85}$, oficiais ${ }^{86}$, entre outras ocupações. Os levantamentos populacionais dos judeus em Portugal entre 1300 e 1499, realizados por Maria José Pimenta Ferro Tavares, não fazem referência a qualquer agente de ensino ${ }^{87}$, e mesmo no que diz respeito aos letrados, apenas são identificados dois doutores da lei, um em Bragança, José Cartilam ${ }^{88}$, o outro em Évora, o rabi Moisés Navarro ${ }^{89}$. Assim sendo, apesar da própria natureza do seu cargo e da própria etimologia da palavra que o designa, não se poderá afirmar que todos os rabis, ou seja, os oficiais designados como chefes civis e religiosos em cada comuna, exerciam atividades de ensino - apenas temos a confirmação do já referido Juda Rabi -, ainda que o exercício da direção espiritual e cultural de uma comunidade estivesse intimamente relacionado com a instrução e a transmissão de conhecimentos. Apesar das diferenças de credo, não seriam muito distintas as motivações que levavam à promoção do Latim e do Direito Canónico na catedral, do Árabe e do Direito Corânico na mesquita, e do Hebraico e da Lei talmúdica na sinagoga e respetivas escolas anexas. Bem diferentes eram, contudo, os condicionalismos.

\section{Conclusão}

26 A expansão do ensino em Évora nos últimos séculos da Idade Média é análoga à multiplicação de escolas um pouco por toda a Cristandade. É fundamental compreender e estudar o desenvolvimento destas escolas e comunidades de cultura em meios urbanos no Portugal medieval. $\mathrm{O}$ acesso a uma literacia básica torna-se mais fácil, também por ser cada vez mais necessário. A escrita, revestida de um caráter oficial e quase sagrado, é prova e memória. O seu conhecimento e a sua utilização são uma mais-valia cada vez menos dispensável e o publico estormento é parte do dia-a-dia do homem tardo-medieval, sobretudo numa cidade. Diferentes grupos procuram garantir uma preparação cada vez mais completa, buscando a manutenção do seu estatuto ou a promoção social. Consegue-a o filho do barbeiro que chega a físico, o sobrinho do cónego que atinge a dignidade episcopal, o filho do mercador eleito vereador, ou o filho do ourives que brilha na escola de gramática e prossegue para um Estudo Geral. A história social do ensino e da cultura acrescenta à questão "o que é estudado?" a pergunta "estudar para quê?". E, de facto, as motivações multiplicam-se com a aproximação do final da Idade Média.

Évora, cidade burguesa, episcopal e régia, constitui um exemplo privilegiado de como uma cidade em crescimento diversifica a sua composição social e potencia a sua oferta cultural. Não é possível estudar estas escolas fora do seu contexto urbano e das suas relações de complementaridade-competição. A atual capital alentejana poderá não ter sido palco de apaixonadas disputationes escolásticas, mas, habituada a ser poiso de reis e rainhas, a receber embaixadores e às maiores festas - e tragédias - do reino, é uma das cidades portuguesas onde é mais evidente - e, por certo, mais compensador e fértil em oportunidades - o crescente interesse do homem comum em aprender. $O$ conhecimento é um investimento de inestimável valia na proteção dos interesses pessoais e coletivos, no exercício do poder e no ingresso no serviço da corte, na prática dos ofícios especializados, enfim, no quotidiano de uma comunidade viva e pulsante. 


\section{BIBLIOGRAFIA}

Fontes manuscritas

Arquivo da Sé de Évora, Cabido da Sé de Évora, Disposições Supra-Capitulares, Autoridades Eclesiásticas,

Cartas de Bispos, Maço 001.

Arquivo da Sé de Évora, Cabido da Sé de Évora, Fazenda, Capelas, Próprios e Foros, Escrituras, Livro 005, fl. $136-137,175 \mathrm{v}-176 \mathrm{v}, 177 \mathrm{v}-178 \mathrm{v}$.

Arquivo da Sé de Évora, Cabido da Sé de Évora, Governo Capitular, Livros de Acórdãos do Cabido, Livro 001 , fls. 13, 33, 39v, 42 e 46.

Arquivo da Sé de Évora, Cabido da Sé de Évora, Serviços Litúrgicos, Livros de Aniversários, Livro I dos Aniversários, fl. 28v.

Arquivo Distrital de Évora, Câmara Municipal de Évora, Livro 67 (Livro 1ํ de Pergaminho), fls. 101v-102; Livro 72 ( $2^{\circ}$ de Originais), fl. 104.

Arquivo Distrital de Évora, Fundo da Misericórdia, Livro 63, fls. 2v, 3, 16-16v, $18 \mathrm{v}-19$.

Arquivo Nacional da Torre do Tombo, Chancelaria Régia, Chancelaria de D. Afonso V, Livro 35, fl. 108v.

Arquivo Nacional da Torre do Tombo, Chancelaria Régia, Chancelaria de D. Manuel I, Livro 16, fl. 75v.

Arquivo Nacional da Torre do Tombo, Leitura Nova, Odiana, Livro 1, fl. 252v-253.

Biblioteca Pública de Évora, Pergaminhos Avulsos, Pasta 04, peça 088.

Fontes impressas

Chancelarias Portuguesas. D. Duarte. Vol. I, T. 2. Org. João José Alves Dias. Lisboa: Centro de Estudos Históricos - Universidade Nova de Lisboa, 1998.

Chancelarias Portuguesas. D. Pedro I. Ed. A. H. de Oliveira Marques. Lisboa: Centro de Estudos Históricos - Universidade Nova de Lisboa, 1984.

Chartularium Universitatis Portucalensis. Volume I (1288-1377). Ed. Artur Moreira de Sá. Lisboa: Instituto de Alta Cultura, 1966.

Chartularium Universitatis Portugalensis. Volume II (1288-1537). Ed. Artur Moreira de Sá. Lisboa: Instituto de Alta Cultura, 1968.

Chartularium Universitatis Portucalensis. Volume VII (1471-1481). Ed. Artur Moreira de Sá. Lisboa: Instituto Nacional de Investigação Científica, 1978.

Cortes Portuguesas. Reinado de D. Manuel I (Cortes de 1498). Dir. A. H. de Oliveira Marques. Lisboa: Centro de Estudos Históricos, Universidade Nova de Lisboa, 2002.

DUARTE, Dom - Leal Conselheiro. Atualização ortográfica, introdução e notas de João Morais Barbosa. Lisboa: Imprensa Nacional - Casa da Moeda, 1983.

Bases de dados

Prosopografía de los ulemas de al-Andalus. [Online]. [Consultado em 06/01/2017]. Disponible en http://www.eea.csic.es/pua/. 
Estudos

AGUIAR, David Emanuel Vieira - D. Diogo de Sousa e as ofertas de bens móveis à Sé de Braga. Braga: Universidade do Minho, 2012. 3 vols. Dissertação de Mestrado.

ALEGRIA, José Augusto - História da Escola de Música da Sé de Évora. Lisboa: Fundação Calouste Gulbenkian, 1973.

ALEGRIA, José Augusto - O ensino e prática da música nas Sés de Portugal: da reconquista aos fins do século XVI. Lisboa: Instituto de Cultura e Língua Portuguesa, 1985.

ALEGRIA, José Augusto - O Colégio dos Moços do Coro da Sé de Évora. Lisboa: Fundação Calouste Gulbenkian, 1997.

ALEXANDRE-BIDON, Danièle; LORCIN, Maria Thérèse - Système éducatif et cultures dans l'Occident médiéval (XII ${ }^{e}-X V^{e}$ siècle). Paris: Éditions Ophrys, 1998.

ASTZALOS, Monika - “A Faculdade de Teologia”. in Uma História da Universidade Europeia. Vol. I: As Universidades na Idade Média. Lisboa: Imprensa Nacional - Casa da Moeda, 1996, pp. 411-443.

BALLESTEROS, Carmen - “A Judiaria e a Sinagoga Medieval de Évora (1ª Campanha de Escavação)”. in BALLESTEROS, Carmen; RUAH, Mery (Coord.) - Os Judeus Sefarditas. Entre Portugal, Espanha e Marrocos. Évora: Edições Colibri, Associação Portuguesa de Estudos Judaicos, CIDEHUS, Universidade de Évora, pp. 191-218.

BAPTISTA, Júlio César - "A formação do Clero na Diocese de Évora". A Cidade de Évora: Boletim de Cultura da Câmara Municipal. $1^{\text {a }}$ Série, 61 (1978), pp. 5-90.

BAPTISTA, Júlio César - "Pergaminhos dos bacharéis da Sé de Évora". A Cidade de Évora: Boletim de Cultura da Câmara Municipal. 1ª Série, 65 (1982), pp. 63-164.

BARROS, Maria Filomena Lopes de - A Comuna Muçulmana de Lisboa: Séculos XIV e XV. Lisboa: Hugin, 1998.

BARROS, Maria Filomena Lopes de - Tempos e Espaços de Mouros. A Minoria Muçulmana no Reino Português (séculos XII a XV). Lisboa: Fundação Calouste Gulbenkian, Fundação para Ciência e Tecnologia, 2007.

BEIRANTE, Ângela - Évora na Idade Média. Lisboa: Fundação Calouste Gulbenkian, Junta Nacional de Investigação Científica e Tecnológica, 1995.

BOTTICINI, Maristella; ECKSTEIN, Zvi - La poignée d'élus. Comment l'éducation a façonné l'histoire juive. 70-1492. Traduction de Pierre-Emmanuel Dauzat. Paris: Albin Michel, 2016.

CAEIRO, Francisco da Gama - "As Escolas Capitulares no primeiro século da Nacionalidade Portuguesa”. Arquivos de História da Cultura Portuguesa. vol. I, no 2 (1966).

COELHO, Maria Helena da Cruz - "Os tabeliães em Portugal, perfil profissional e sócioeconómico". in OSTOS, Pilar; PARDO, Maria Luisa (Eds.) - Estudios sobre el Notariado Europeo (Siglos XIV-XV). Sevilla: Universidad de Sevilla, 1997, pp. 11-51.

CUNHA, Maria Cristina Almeida e - "Tabeliães bracarenses no século XIII”. in IX Congresso da Dedicação da Sé de Braga. Actas - Volume II/1. A Catedral de Braga na História e na Arte (séculos XII-XIII). Braga: Faculdade de Teologia, Universidade Católica Portuguesa, Cabido Metropolitano e Primacial de Braga, 1990, pp. 249-265.

CUNHA, Maria Cristina Almeida e - "Tabeliães de Bragança no século XIV: da legislação à praxis". in Estudos em Homenagem ao Professor Doutor José Marques. Porto: Universidade do Porto, Faculdade de Letras, 2006, pp. 313-324. 
FERRO, Maria José Pimenta - Os Judeus em Portugal no Século XIV. $2^{a}$ edição. Lisboa: Guimarães Editores, 2000.

GONÇALVES, Iria - "Físicos e Cirurgiões Quatrocentistas: As Cartas de Exame”. Do Tempo e Da História I (1972), pp. 69-112.

LOPES, Francisco Félix - "Escolas Públicas dos Franciscanos em Portugal antes de 1308". Colectânea de Estudos. Suplementos do Boletim Mensal 2 (1947), pp. 83-108.

LOPES, Francisco Félix - "Escolas Franciscanas Portuguesas de 1308 a 1570”. Colectânea de Estudos. Suplementos do Boletim Mensal 4 (1948), pp. 78-98.

LOPES, Francisco Félix - "Franciscanos portugueses pretridentinos escritores, mestres e leitores". Repertorio de Historia de las Ciencias Eclesiasticas en España 7 (1979), pp. 451-508.

MARÍN, Manuela - "Movilidad social y ciencias islâmicas: ejemplos biográficos andalusíes de la Baja Edad Media". in VILAR, Hermínia Vasconcelos; BARROS, Maria Filomena Lopes de (Eds.) Categorias sociais e mobilidade urbana na Baixa Idade Média. Lisboa: Edições Colibri, CIDEHUS, 2012, pp. 11-34.

MATTOSO, José - “Espiritualidade. I. Época Medieval”. in AZEVEDO, Carlos Moreira (Dir.) Dicionário de história religiosa de Portugal. Lisboa: Círculo de Leitores, 2000, vol. 2, pp. 181-186.

MATTOSO, José - Religião e Cultura na Idade Média Portuguesa. Rio de Mouro: Círculo de Leitores, 2002.

MOHEDANO BARCELÓ, José - Ibn Abdun de Évora. Évora: Publicações Universidade de Évora, 1982. NOGUEIRA, Bernardo Sá - Tabelionado e Instrumento Público em Portugal. Génese e Implantação (1212-1279). Lisboa: Imprensa Nacional - Casa da Moeda, 2008.

NORTE, Armando José Gomes do - Letrados e Cultura Letrada em Portugal (sécs. XII e XIII). Lisboa: Faculdade de Letras da Universidade de Lisboa, 2013. 2 vols. Tese de Doutoramento.

PEREIRA, Isaías da Rosa - "O Tabelionado em Portugal”. in VII Congreso Internacional de Diplomática - Notariado público y documento privado: De los orígenes al siglo XIV. Valencia: Generalitat Valenciana, Conselleria de Cultura, Educacio i Ciència, 1986, vol. 1, pp. 669-674.

ROLDÃO, Filipa - A memória da cidade. Administração urbana e práticas de escrita em Évora (1415-1536). Lisboa: Faculdade de Letras da Universidade de Lisboa, 2011. Tese de Doutoramento.

ROLO, Raul A. - "Dominicanos". in AZEVEDO, Carlos Moreira (Dir.) - Dicionário de história religiosa de Portugal. Lisboa: Círculo de Leitores, 2000, vol. 2, pp. 82-88.

ROSÁRIO, António do - Pergaminhos dos conventos dominicanos. I Série: Elementos de interesse para o estudo geral português. Lisboa: [Instituto de Alta Cultura], 1972.

ROSÁRIO, António do - "Frades Pregadores em intercâmbio peninsular, séc. XIII". in Actas das II Jornadas Luso-Espanholas de História Medieval. Porto: Instituto Nacional de Investigação Científica, 1990, vol. IV, pp. 1251-1272.

RUËGG, Walter - “Temas”. in RIDDER-SYMOENS, Hilde (Coord.) - Uma História da Universidade Europeia. Vol. I: As Universidades na Idade Média. Lisboa: Imprensa Nacional - Casa da Moeda, 1996, pp. 3-31.

SANTOS, Maria José Azevedo - "Sobre os tabeliães de Coimbra: Alguns aspectos do tabelionado em Coimbra: séculos XIV-XV”. Separata do Arquivo Coimbrão 33-34. Coimbra: [s.n.], 1993.

SARAIVA, Anísio Miguel de Sousa - “Tabeliães e Notários de Lamego na Primeira Metade do séc. XIV”. Humanitas 50, tomo I (1998), pp. 587-624. 
SCHWINGES, Rainer Cristoph - "Formação dos Estudantes e Vida Estudantil”. in RIDDERSYMOENS, Hilde (Coord.) - Uma História da Universidade Europeia. Vol. I: As Universidades na Idade Média. Lisboa: Imprensa Nacional - Casa da Moeda, 1996, pp. 171-193.

SEABRA, Ricardo - Publicus tabellio in civitatis portugalensis: estudo sobre o tabelionado no Porto medieval (1242-1383). Porto: Faculdade de Letras da Universidade do Porto, 2012. Dissertação de Mestrado.

ŞENOCAK, Neslihan - "Franciscan Studium Generale: A New Interpretation". in EMERY Jr, K.; COURTENAY, William; METZGER, Stephen M. (Eds.) - Philosophy and Theology in the Studia of the Religious Orders and at the Papal Court. Turnhout: Brepols Publishers, 2012, pp. 221-236.

SILVA, André Filipe Oliveira da - Físicos e Cirurgiões Medievais Portugueses. Contextos Socioculturais, Praticas e Transmissão de Conhecimentos (1192-1340). Porto: CITCEM, 2016.

SILVA, Maria João Oliveira - "Probationes pennae: enseñar y aprender a escribir en los monasterios de la diócesis de Oporto en la edad media". in Lugares de escritura: el monasterio. XI Jornadas de Ciencias y Técnicas Historiográficas. Alicante: Publicacions Universitat d'Alacant, 2016, pp. 287-294.

SOUSA, Armindo de - As Cortes Medievais Portuguesas: 1385-1490. Lisboa: Instituto Nacional de Investigação Científica, 1990.

TAVARES, Maria José Pimenta Ferro - Os Judeus em Portugal no Século XV. Vol. I. Lisboa: Universidade Nova de Lisboa - Faculdade de Ciências Sociais e Humanas, 1982.

TAVARES, Maria José Pimenta Ferro - Os Judeus em Portugal no Século XV. Vol. II. Lisboa: Instituto Nacional de Investigação Científica, 1984.

VERGER, Jacques - “Modelos”. in RIDDER-SYMOENS, Hilde (Coord.) - Uma História da Universidade Europeia. Vol. I: As Universidades na Idade Média. Lisboa: Imprensa Nacional - Casa da Moeda, 1996, pp. 33-71.

VILAR, Hermínia Vasconcelos - As Dimensões de um Poder. A Diocese de Évora na Idade Média. Lisboa: Editorial Estampa, 1999.

ZIEGLER, Joseph - "Medicine and the body at the table in fourteenth-century Italy: Book of Philip of Ferrara's Liber de Introdutione Loquendi”. in GLAZE, Florence Eliza; NANCE, Brian K. (Eds.) Between Text and Patient. The Medical Enterprise in Medieval \& Early Modern Europe. Firenze: SISMEL/ Edizioni del Galluzzo, 2011, pp. 121-136.

\section{NOTAS}

1. RUËGG, Walter - “Temas”. in RIDDER-SYMOENS, Hilde (Coord.) - Uma História da Universidade Europeia. Vol. I: As Universidades na Idade Média. Lisboa: Imprensa Nacional - Casa da Moeda, 1996, pp. 3-31; VERGER, Jacques - "Modelos". in RIDDER-SYMOENS, Hilde (Coord.) - Uma História da Universidade Europeia, pp. 33-71.

2. Como exemplo, refira-se a criação da Universidade de Toulouse após a Cruzada Albigense, como meio de combate da heresia através do ensino 'oficial' e vigiado, ainda que essa motivação se tenha esbatido posteriormente. VERGER, Jacques - "Modelos", p. 51.

3. VILAR, Hermínia Vasconcelos - As Dimensões de um Poder. A Diocese de Évora na Idade Média. Lisboa: Editorial Estampa, 1999, p. 245.

4. Os estudos sobre a escola catedralícia eborense escasseiam. Pela sua extensão documental e cronológica, destaca-se BAPTISTA, Júlio César - "A formação do Clero na Diocese de Évora". A Cidade de Évora: Boletim de Cultura da Câmara Municipal. 1ª Série, 61 (1978), pp. 5-90; ao contrário de 
Braga, Coimbra e Lisboa, Évora foi apenas referida - e não analisada -, no estudo pioneiro realizado por Gama Caeiro: CAEIRO, Francisco da Gama - "As Escolas Capitulares no primeiro século da Nacionalidade Portuguesa". Arquivos de História da Cultura Portuguesa, vol. I, no 2 (1966). O ensino da música na Sé foi longamente estudado pelo cónego eborense José Augusto Alegria, ainda que com enfoque no século XVI e XVII: ALEGRIA, José Augusto - História da Escola de Música da Sé de Évora. Lisboa: Fundação Calouste Gulbenkian, 1973; ALEGRIA, José Augusto - $O$ ensino e prática da música nas Sés de Portugal: da reconquista aos fins do século XVI. Lisboa: Instituto de Cultura e Língua Portuguesa, 1985; ALEGRIA, José Augusto - o Colégio dos Moços do Coro da Sé de Évora. Lisboa: Fundação Calouste Gulbenkian, 1997.

5. CAEIRO, Francisco da Gama - "As Escolas Capitulares", pp. 5-7.

6. CAEIRO, Francisco da Gama - "As Escolas Capitulares”, pp. 12-30.

7. VILAR, Hermínia Vasconcelos - As Dimensões de um Poder, pp. 28-31.

8. São exemplo os cónegos Mestre Domingos, documentado em 1200, e Mestre Vicente, documentado entre 1218 e 1220. VILAR, Hermínia Vasconcelos - As Dimensões de um Poder, pp. 345, 402; NORTE, Armando José Gomes do - Letrados e Cultura Letrada em Portugal (sécs. XII e XIII), 2 vols., Lisboa: Universidade de Lisboa, 2013. Tese de Doutoramento, vol. II, pp. 33-34, 328-329.

9. VILAR, Hermínia Vasconcelos - As Dimensões de um Poder, p. 245.

10. VILAR, Hermínia Vasconcelos - As Dimensões de um Poder, pp. 156-160.

11. BAPTISTA, Júlio César - "A formação do Clero", p. 15.

12. Júlio César Baptista publicou os sumários dos pergaminhos do fundo dos Bacharéis, existentes no Arquivo da Sé de Évora, revelando a existência de um património próprio pelo menos desde 1295, assim como uma existência organizada desde muito cedo e em constante conflito com o Cabido: BAPTISTA, Júlio César - "Pergaminhos dos bacharéis da Sé de Évora”. A Cidade de Évora: Boletim de Cultura da Câmara Municipal. $1^{\text {a }}$ Série, 65 (1982), pp. 63-164.

13. VILAR, Hermínia Vasconcelos - As Dimensões de um Poder, pp. 185-186.

14. D. Diogo de Sousa terá nascido em Évora, em 1460. A sua ação como prelado do Porto e Braga levou os vários autores que sobre ele escreveram a concentrar os seus trabalhos nesses aspetos, ficando muito por estudar das suas primeiras décadas de vida. Para um estado da arte sobre este prelado e a sua ação, cf. AGUIAR, David Emanuel Vieira - D. Diogo de Sousa e as ofertas de bens móveis à Sé de Braga, 3 vols., Braga: Universidade do Minho, 2012. Dissertação de Mestrado, pp. 11-22; a idade que Diogo de Sousa teria à altura não só não põe em causa a identificação, como a reforça. A sua matrícula na cadeira de Gramática indica que daria início ao seu percurso na aprendizagem formal do Latim. Seria, portanto, scolaris simplex, encaixando na perfeição na descrição feita por Rainer Cristoph Schwinges: "O estudante [de Artes] é, na maioria dos casos um jovem entre os catorze e os dezasseis anos que, por norma, se matricula numa universidade pela primeira vez e corresponde, tanto quanto lhe é possível, às condições legais e financeiras prescritas para a admissão. [...] Este estudante frequentou, muito provavelmente, a escola de Latim da sua região natal e adquiriu pelo menos um conhecimento básico da leitura, da escrita e da gramática latina.", cf. SCHWINGES, Rainer Cristoph - "Formação dos Estudantes e Vida Estudantil". in RIDDER-SYMOENS, Hilde (Coord.) - Uma História da Universidade Europeia, pp. 196-197. Esta possibilidade sai reforçada pelas referências a um Diogo de Sousa, estudante de Direito Canónico na Universidade de Lisboa, feita numa bula de 1474, que o contempla com meia prebenda no Cabido de Évora, entre outros benefícios, assim como noutra bula, de 1475, onde é novamente contemplado com meia prebenda no Cabido eborense, denominado como clérigo de Évora, sendo referida a sua ligação ao Estudo de Lisboa e a sua origem nobre: Chartularium Universitatis Portucalensis. Volume VII (1471-1481). Ed. Artur Moreira de Sá. Lisboa: Instituto Nacional de Investigação Científica, 1978, pp. 197-200, 264-265. Agradeço a um dos revisores anónimos deste artigo a chamada de atenção para estas duas bulas.

15. Arquivo da Sé de Évora, Cabido da Sé de Évora, Governo Capitular, Livros de Acórdãos do Cabido, Livro 001, fl. 13. O documento foi já publicado por Gabriel Pereira nos Documentos Históricos da 
Cidade de Évora, entre vários outros excertos deste livro de acórdãos, assim como por Júlio César Baptista, no seu artigo sobre a formação do clero eborense.

16. BAPTISTA, Júlio César - “A formação do Clero", pp. 8-11.

17. Arquivo da Sé de Évora [ASE], Cabido da Sé de Évora, Disposições Supra-Capitulares, Autoridades Eclesiásticas, Cartas de Bispos, Maço 001. Como a mais recente catalogação dos documentos do ASE omite, quase sempre, uma identificação individual dos documentos avulsos, refira-se ainda a cota atribuída a este documento no inventário de Carlos da Silva Tarouca, de 1946: Cartas dos Bispos, EE 17a.

18. BAPTISTA, Júlio César - “A formação do Clero", pp. 22-37.

19. Arquivo da Sé de Évora, Cabido da Sé de Évora, Serviços Litúrgicos, Livros de Aniversários, Livro I dos Aniversários, fl. $28 \mathrm{v}$.

20. BAPTISTA, Júlio César - “A formação do Clero”, pp. 46-67.

21. VILAR, Hermínia Vasconcelos - As Dimensões de um Poder, pp. 289-300. Nas regiões portuguesas onde os mosteiros beneditinos e agostinianos eram numerosos e predominantes, as suas escolas representavam mais um meio de aprendizagem possível: SILVA, Maria João Oliveira - "Probationes pennae: enseñar y aprender a escribir en los monasterios de la diócesis de Oporto en la edad media". in Lugares de escritura: el monasterio. XI Jornadas de Ciencias y Técnicas Historiográficas. Alicante: Publicacions Universitat d'Alacant, 2016, pp. 287-294.

22. BEIRANTE, Ângela - Évora na Idade Média. Lisboa: Fundação Calouste Gulbenkian, Junta Nacional de Investigação Científica e Tecnológica, 1995, pp. 91-95.

23. ROLO, Raul A. - "Dominicanos". in AZEVEDO, Carlos Moreira (Dir.) - Dicionário de história religiosa de Portugal. Lisboa: Círculo de Leitores, 2000, vol. 2, pp. 82.

24. Os conventos lisboetas acolherão as mais importantes escolas mendicantes portuguesas, havendo notícia da existência de um estudo geral instalado no Convento de São Francisco de Lisboa já em 1340: Chartularium Universitatis Portucalensis. Volume I (1288-1377), Ed. Artur Moreira de Sá. Lisboa: Instituto de Alta Cultura, 1966, pp. 134;

25. ASTZALOS, Monika - "A Faculdade de Teologia". in RIDDER-SYMOENS, Hilde (Coord.) - Uma História da Universidade Europeia, pp. 411-443.

26. MATTOSO, José - “Espiritualidade. I. Época Medieval”. in AZEVEDO, Carlos Moreira (Dir.) Dicionário de história religiosa de Portugal. Lisboa: Círculo de Leitores, 2000, vol. 2, p. 186.

27. ROSÁRIO, António do - "Frades Pregadores em intercâmbio peninsular, séc. XIII". in Actas das II Jornadas Luso-Espanholas de História Medieval. Porto: Instituto Nacional de Investigação Científica, 1990, vol. IV, p. 1272.

28. LOPES, Francisco Félix - "Franciscanos portugueses pretridentinos escritores, mestres e leitores". Repertorio de Historia de las Ciencias Eclesiasticas en España 7 (1979), p. 460; ROSÁRIO, António do - Pergaminhos dos conventos dominicanos. I Série: Elementos de interesse para o Estudo Geral português. Lisboa:[Instituto de Alta Cultura], 1972, pp. 17-19.

29. Chartularium Universitatis Portucalensis. Volume I, pp. 12-15.

30. LOPES, Francisco Félix - "Franciscanos portugueses pretridentinos", p. 466. Para as primeiras oito décadas do convento franciscano de Évora, a existência de uma escola é, segundo Félix Lopes, conjetural: LOPES, Francisco Félix - "Escolas Públicas dos Franciscanos em Portugal antes de 1308”. Colectânea de Estudos. Suplementos do Boletim Mensal 2 (1947), pp. 106-108. De 1308 até ao final da Idade Média, os dados não são mais abundantes, com exceção do já referido leitor documentado em 1330: LOPES, Francisco Félix - "Escolas Franciscanas Portuguesas de 1308 a 1570". Colectânea de Estudos. Suplementos do Boletim Mensal 4 (1948), pp. 78-98.

31. Neslihan şenocak explora esta complexificação, tornando evidente a existência de tipos diferentes de escolas franciscanas: as simples escolas, os studia e os studia generalia; a evolução dos conventos portugueses torna-se, assim, mais explícita: em 1336, não existe nenhum studium franciscano na Península Ibérica, mas em 1340 é criado um studium generale no convento lisboeta da Ordem, tornando-o um destino provável para muitos dos frades menores eborenses assim 
como um fornecedor privilegiado de leitores ao convento de Évora. Por tudo, ver şENOCAK, Neslihan - "Franciscan Studium Generale: A New Interpretation". in EMERY Jr, K.; COURTENAY, William; METZGER, Stephen M. (Eds.) - Philosophy and Theology in the Studia of the Religious Orders and at the Papal Court. Turnhout: Brepols Publishers, 2012, pp. 221-236.

32. LOPES, Francisco Félix - "Franciscanos portugueses pretridentinos", pp. 464-466.

33. LOPES, Francisco Félix - "Franciscanos portugueses pretridentinos", pp. 475-476.

34. Chartularium Universitatis Portucalensis. Volume VII (1471-1481). Ed. Artur Moreira de Sá. Lisboa: Instituto Nacional de Investigação Científica, 1978, p. 456; ROSÁRIO, António do - "Letrados Dominicanos nos Séculos XIII-XV". Repertorio de Historia de las Ciencias Eclesiasticas en España 7 (1979), p. 596.

35. ROSÁRIO, António do - "Letrados Dominicanos", pp. 557-558.

36. Todo o conhecimento era um meio de pregação e todas as ocasiões ideais: exemplo disso é o trecentista Liber de Introdutione Loquendi, do dominicano Filipe de Ferrara, que ensina a aproveitar um contexto de banquete para pregar, recorrendo, por exemplo, a metáforas médicas. ZIEGLER, Joseph - "Medicine and the body at the table in fourteenth-century Italy: Book of Philip of Ferrara's Liber de Introdutione Loquendi". in GLAZE, Florence Eliza; NANCE, Brian K. (Eds.) - Between Text and Patient. The Medical Enterprise in Medieval \& Early Modern Europe. Firenze: SISMEL/Edizioni del Galluzzo, 2011, pp. 121-136.

37. SOUSA, Armindo de - As Cortes Medievais Portuguesas: 1385-1490. 2 vols. Lisboa: Instituto Nacional de Investigação Científica, 1990, vol. I, pp. 217-219.

38. Cortes Portuguesas. Reinado de D. Manuel I (Cortes de 1498). Dir. A. H. de Oliveira Marques. Lisboa: Centro de Estudos Históricos, Universidade Nova de Lisboa, 2002, p. 66.

39. Todos os contratos dizem respeito ao último terço do século $\mathrm{XV}$, havendo um com um carpinteiro, outro com um telheiro e um terceiro com um pedreiro. Arquivo da Sé de Évora, Cabido da Sé de Évora, Governo Capitular, Livros de Acórdãos do Cabido, Livro 001, fl. 39v, 42 e 46.

40. Arquivo Nacional da Torre do Tombo, Chancelaria Régia, Chancelaria de D. Afonso V, Livro 35, fl. $108 \mathrm{v}$.

41. Arquivo Distrital de Évora, Câmara Municipal de Évora, Livro 72 (2ํㅡㄹ de Originais), fl. 104.

42. Arquivo Distrital de Évora, Fundo da Misericórdia, Livro 63, fl. 2v, 3 e 16-16v, respetivamente.

43. Arquivo Distrital de Évora, Câmara Municipal de Évora, Livro 67 (Livro $1^{\circ}$ de Pergaminho), fls. $101 \mathrm{v}-102$.

44. Arquivo Distrital de Évora, Fundo da Misericórdia, Livro 63, fl. 18v-19.

45. Chartularium Universitatis Portugalensis (1288-1537), vol. 2. Ed. e compilação Artur Moreira de Sá. Lisboa: Instituto de Alta Cultura, 1968, p. 184, doc. 433. Uma vez mais, agradeço a um dos revisores anónimos deste artigo a chamada de atenção para esta referência.

46. O catálogo prosopográfico de dignidades e cónegos da Sé de Évora elaborado por Hermínia Vasconcelos Vilar para o período compreendido entre 1165 e 1423 não faz referência a qualquer Estêvão Eanes: VILAR, Hermínia Vasconcelos - As Dimensões de um Poder, pp. 315-403.

47. BEIRANTE, Ângela - Évora na Idade Média, p. 502.

48. GONÇALVES, Iria - "Físicos e Cirurgiões Quatrocentistas: As Cartas de Exame". Do Tempo e Da História I (1972), pp. 69-112. Antes do século XV, houve uma primeira tentativa de examinar todos os candidatos ao ofício de físico e cirurgião, levada a cabo por D. Afonso IV, entre 1338 e 1340: SILVA, André Filipe Oliveira da - Físicos e Cirurgiões Medievais Portugueses. Contextos Socioculturais, Práticas e Transmissão de Conhecimentos (1192-1340). Porto: CITCEM, 2016, pp. 122-124.

49. SILVA, André Filipe Oliveira da - Físicos e Cirurgiões Medievais, pp. 98-101.

50. GONÇALVES, Iria - "Físicos e Cirurgiões", p. 98.

51. GONÇALVES, Iria - "Físicos e Cirurgiões", p. 101.

52. GONÇALVES, Iria - "Físicos e Cirurgiões", p. 100.

53. GONÇALVES, Iria - "Físicos e Cirurgiões", p. 104. 
54. TAVARES, Maria José Pimenta Ferro - Os Judeus em Portugal no Século XV. Vol. II. Lisboa: Instituto Nacional de Investigação Científica, 1984, pp. 108, 800.

55. DUARTE, Dom - Leal Conselheiro. Atualização ortográfica, introdução e notas de João Morais Barbosa. Lisboa: Imprensa Nacional - Casa da Moeda, 1983, p. 44.

56. Arquivo Nacional da Torre do Tombo, Chancelaria Régia, Chancelaria de D. Manuel I, Livro 16, fl. $75 \mathrm{v}$.

57. O tabelionado público terá surgido em Portugal no reinado de D. Afonso II, tendo desaparecido da maior parte do reino durante o reinado de D. Sancho II, regressando e consolidando-se durante o governo de D. Afonso III. Bernardo Sá Nogueira estuda cada uma destas fases nos capítulos 2, 3 e 4 da sua tese de doutoramento, respetivamente: NOGUEIRA, Bernardo Sá - Tabelionado e Instrumento Público em Portugal. Génese e Implantação (1212-1279). Lisboa: Imprensa Nacional - Casa da Moeda, 2008, pp. 55-230, 231-310 e 311-511.

58. NOGUEIRA, Bernardo Sá - Tabelionado e Instrumento Público, pp. 544-545.

59. Entre estes, destacam-se: CUNHA, Maria Cristina Almeida e - "Tabeliães bracarenses no século XIII". in IX Congresso da Dedicação da Sé de Braga. Actas - Volume II/1. A Catedral de Braga na História e na Arte (séculos XII-XIII). Braga: Faculdade de Teologia, Universidade Católica Portuguesa, Cabido Metropolitano e Primacial de Braga, 1990, pp. 249-265; CUNHA, Maria Cristina Almeida e “Tabeliães de Bragança no século XIV: da legislação à praxis”. in Estudos em Homenagem ao Professor Doutor José Marques. Porto: Faculdade de Letras, Universidade do Porto, 2006, pp. 313-324; SARAIVA, Anísio Miguel de Sousa - "Tabeliães e Notários de Lamego na Primeira Metade do séc. XIV”. Humanitas, vol. 50, tomo I (1998), pp. 587-624; SEABRA, Ricardo - Publicus tabellio in civitatis portugalensis: estudo sobre o tabelionado no Porto medieval (1242-1383). Porto: Faculdade de Letras da Universidade do Porto, 2012. Dissertação de Mestrado; SANTOS, Maria José Azevedo - "Sobre os tabeliães de Coimbra: Alguns aspectos do tabelionado em Coimbra: séculos XIV-XV". Separata do Arquivo Coimbrão 33-34. Coimbra: [s.n.], 1993. Nota também para a tese de doutoramento de Filipa Roldão que, não sendo dedicado ao tabelionado eborense, estuda com profundidade o papel da escrita no exercício do poder na cidade: ROLDÃo, Filipa - A memória da cidade. Administração urbana e práticas de escrita em Évora (1415-1536). Lisboa: Universidade de Lisboa, 2011. Tese de Doutoramento.

60. Apesar de o primeiro regimento conhecido do tabelionado português datar de 1305, e apenas então ter sido expressa a proibição do exercício do notariado público a clérigos, dificilmente se poderá considerar este regimento como original e aceitar que o tabelionado tivesse permanecido por regular até então. Assim, Bernardo Sá Nogueira considera o Regimento de 1305 uma sistematização de normas anteriores, provavelmente emanadas durante o reaparecimento e consolidação do tabelionado público em Portugal, no reinado de D. Afonso III (1248-1279): NOGUEIRA, Bernardo Sá - Tabelionado e Instrumento Público, pp. 44-49. Este regimento foi publicado em: PEREIRA, Isaías da Rosa - "O Tabelionado em Portugal”. in VII Congreso Internacional de Diplomática - Notariado público y documento privado: De los orígenes al siglo XIV. Valencia: Generalitat Valenciana, Conselleria de Cultura, Educacio i Ciència, 1986, vol. 1, pp. 669-674.

61. NOGUEIRA, Bernardo Sá - Tabelionado e Instrumento Público, pp. 17-40.

62. José Mattoso deteta o uso da ars dictandi de origem italiana no cartório monástico de Pendorada, logo no final do século XII. MATTOSO, José - Religião e Cultura na Idade Média Portuguesa. Rio de Mouro: Círculo de Leitores, 2002, p. 220.

63. COELHO, Maria Helena da Cruz - "Os tabeliães em Portugal, perfil profissional e sócioeconómico". in OSTOS, Pilar; PARDO, Maria Luisa (Eds.) - Estudios sobre el Notariado Europeo (Siglos XIV-XV). Sevilla: Universidad de Sevilla, 1997, p. 19.

64. COELHO, Maria Helena da Cruz - "Os tabeliães em Portugal”, pp. 19-20.

65. Chancelarias Portuguesas. D. Duarte. Org. João José Alves Dias. Lisboa: Centro de Estudos Históricos, Universidade Nova de Lisboa, 1998, vol. I, tomo 2, p. 118. 
66. MOHEDANO BARCELÓ, José - Ibn Abdun de Évora. Évora: Publicações Universidade de Évora, 1982, pp. 9-12. Tendo nascido em Évora, os seus estudos terão sido feitos na capital do reino taifa de Badajoz, não havendo dados sobre as escolas eborenses do período andalusi. A cultura, sempre ligada à religião, revelava-se como um poderoso veículo de mobilidade social: MARÍN, Manuela "Movilidad social y ciencias islâmicas: ejemplos biográficos andalusíes de la Baja Edad Media". in VILAR, Hermínia Vasconcelos; BARROS, Maria Filomena Lopes de (Eds.) - Categorias sociais e mobilidade urbana na Baixa Idade Média. Lisboa: Edições Colibri, CIDEHUS, 2012, pp. 11-34. Ainda que esta realidade diga respeito ao território de domínio muçulmano, não se poderá excluir uma permanência de modelos entre as comunidades que viveram sob domínio cristão.

67. Prosopografía de los ulemas de al-Andalus. [Online]. [Consultado em 06/01/2017]. Disponible en http://www.eea.csic/pua/

68. BARROS, Maria Filomena Lopes de - Tempos e Espaços de Mouros. A Minoria Muçulmana no Reino Português (séculos XII a XV). Lisboa: Fundação Calouste Gulbenkian, Fundação para Ciência e Tecnologia, 2007, pp. 533-535.

69. BARROS, Maria Filomena Lopes de - A Comuna Muçulmana de Lisboa: Séculos XIV e XV. Lisboa: Hugin, 1998, pp. 145-148.

70. Chancelarias Portuguesas. D. Pedro I. Ed. A. H., de Oliveira Marques. Lisboa: Centro de Estudos Históricos, Universidade Nova de Lisboa, 1984, pp. 344-345.

71. TAVARES, Maria José Pimenta Ferro - Os Judeus em Portugal no Século XV. Vol. I. Lisboa: Faculdade de Ciências Sociais e Humanas, Universidade Nova de Lisboa, 1982, p. 351.

72. FERRO, Maria José Pimenta - Os Judeus em Portugal no Século XIV. $2^{\mathrm{a}}$ edição. Lisboa: Guimarães Editores, 2000, pp. 44-45.

73. TAVARES, Maria José Pimenta Ferro - Os Judeus em Portugal no Século XV, vol. I, p. 75.

74. ALEXANDRE-BIDON, Danièle; LORCIN, Maria Thérèse - Système éducatif et cultures dans l'Occident médiéval (XII $-X V^{e}$ siècle). Paris: Éditions Ophrys, 1998, pp. 101-108.

75. BOTTICINI, Maristella; ECKSTEIN, Zvi - La poignée d'élus. Comment l'éducation a façonné l'histoire juive. 70-1492. Traduction de Pierre-Emmanuel Dauzat. Paris: Albin Michel, 2016, sobretudo pp. 163-269.

76. Arquivo Nacional da Torre do Tombo, Leitura Nova, Odiana, Livro 1, fl. 252v-253.

77. Arquivo da Sé de Évora, Cabido da Sé de Évora, Fazenda, Capelas, Próprios e Foros, Escrituras, Livro 005 , fl. 136-137, 175v-176v, 177v-178v.

78. Com base na correspondência das ruas no mapa publicado em TAVARES, Maria José Pimenta Ferro - Os Judeus em Portugal no Século XV, vol. I, p. 60; na sua listagem de topónimos urbanos, Ângela Beirante identifica a Rua do Midras como sendo a atual Travessa do Pocinho, omitindo a existência da Rua do Midras de Baixo: BEIRANTE, Ângela - Évora na Idade Média, p. 195. Conhecendo a existência de referências a este segundo arruamento, a minha preferência de correspondência recaiu sobre a proposta de Maria José Pimenta Ferro. Um exemplo documental dessa denominação: Biblioteca Pública de Évora, Pergaminhos Avulsos, Pasta 04, peça 088.

79. Mesmo com uma escavação limitada, foi possível demonstrar que a planta do atual imóvel, um alojamento local, ainda mantém alguma proximidade àquela que terá sido a da Sinagoga Grande da Judiaria eborense: BALLESTEROS, Carmen - "A Judiaria e a Sinagoga Medieval de Évora (1ª Campanha de Escavação)". in BALLESTEROS, Carmen; RUAH, Mery (Coord.) - Os Judeus Sefarditas. Entre Portugal, Espanha e Marrocos. Évora: Edições Colibri, Associação Portuguesa de Estudos Judaicos, CIDEHUS, Universidade de Évora, 2004, pp. 205-216.

80. Arquivo da Sé de Évora, Cabido da Sé de Évora, Governo Capitular, Livros de Acórdãos do Cabido, Livro 001, fl. 33.

81. TAVARES, Maria José Pimenta Ferro - Os Judeus em Portugal no Século XV, vol. I, p. 84.

82. TAVARES, Maria José Pimenta Ferro - Os Judeus em Portugal no Século XV, vol. I, p. 166.

83. TAVARES, Maria José Pimenta Ferro - Os Judeus em Portugal no Século XV, vol. II, pp. 659, 660, 673, 674, 675, 679, 684, 687. 
84. São disso exemplo Mestre Moisés, rabi-mor e físico de D. João I, Mestre Guedelha, também rabi-mor, físico de D. Duarte, astrólogo da corte e escrivão da Câmara, e o seu filho Mestre Abraão, também físico régio, escrivão da câmara e contador das comunas do reino. TAVARES, Maria José Pimenta Ferro - Os Judeus em Portugal no Século XV, vol. II, pp. 174, 395, 692; 185, 396, 662, 692, 784, 787; 207, 663, 692, 769, 790.

85. TAVARES, Maria José Pimenta Ferro - Os Judeus em Portugal no Século XV, vol. II, p. 683.

86. TAVARES, Maria José Pimenta Ferro - Os Judeus em Portugal no Século XV, vol. II, p. 77.

87. TAVARES, Maria José Ferro - Os Judeus em Portugal no Século XIV, pp. 157-159; TAVARES, Maria José Pimenta Ferro - Os Judeus em Portugal no Século XV, vol. II.

88. TAVARES, Maria José Pimenta Ferro - Os Judeus em Portugal no Século XV, vol. II, p. 657.

89. TAVARES, Maria José Pimenta Ferro - Os Judeus em Portugal no Século XV, vol. II, p. 683.

\section{RESUMOS}

Preservados pelos seus refúgios eclesiásticos, a cultura erudita, a escrita e o ensino expandem-se na Baixa Idade Média, multiplicando-se a oferta de acordo com os destinatários e as suas motivações. A mobilidade social que uma boa educação poderia trazer, as necessidades de uma hierarquia eclesiástica cada vez mais exigente, a especialização dentro das administrações central e local, a especificidade das minorias étnico-religiosas ou o prestígio associado ao saber, sagrado ou profano, são alguns dos fatores responsáveis pelo surgimento de diversos estabelecimentos de ensino. Évora, sede de concelho, cidade episcopal e destino frequente da Corte Régia, revela-se como um excelente caso de estudo desta expansão tardo-medieval, intimamente ligada com a dinâmica de uma cidade em crescimento.

Preserved by their ecclesiastical sanctuaries, the erudite culture, the writing and reading and school education expand during the Late Middle Ages, with an augmenting supply adapted to its recipients and their motivations. The social mobility that a good education could bring, the needs of an increasingly demanding ecclesiastical hierarchy, the specialization within the central and local administrations, the specificities of the religious minorities, as well as the prestige associated with high culture, are some of the factors responsible for the creation of these new schools. Évora, municipality, episcopal city and frequent stop of the Royal Court, reveals itself as an excellent case study of this late medieval expansion, intimately connected to the dynamics of a growing city.

\section{ÍNDICE}

Keywords: Évora, medieval teaching, medieval schools, religious minorities

Palavras-chave: Évora, ensino medieval, escolas medievais, minorias religiosas 


\section{AUTOR}

\section{ANDRÉ FILIPE OLIVEIRA DA SILVA}

Universidade do Porto, Centro de Investigação Transdisciplinar "Cultura, Espaço e Memória" Centro Interdisciplinar de História, Culturas e Sociedades, Universidade de Évora, 4150-564, Porto, Portugal

afosilva@uevora.pt 